LAERE MIDDEL ODK

\title{
Den teknologisk myndige borger
}

- om hvordan kritiske perspektiver på teknologiens rolle i samfundet kan bidrage til teknologiforståelse i folkeskolen

Af Anders Stig Christensen og Morten Velsing Nielsen 
Målet med artiklen er at bidrage til udviklingen af en kritisk og demokratisk tilgang til, hvad en digital myndiggørelse kan indebære i teori og praksis. I forsøgsfaget teknologiforståelse er digital myndiggørelse et af fire kompetenceområder, og fagets ambition er "danne og uddanne eleverne" til at være "aktive, kritiske og demokratiske borgere". I artiklen argumenterer vi for, at den nuværende beskrivelse af digital myndiggørelse i forsøgsfaget er for snævert fokuseret på design og redesign af digitale artefakter. Artiklens bidrag er derfor en tilgang, som fremhæver elevernes muligheder for kritisk at tage stilling og handle i forhold til teknologiens rolle i samfundet. Dette underbygges teoretisk og med eksempler. Artiklen kan inspirere til den videre udvikling af digital myndiggørelse i skolens fag samt mere avancerede diskussioner af digital myndiggørelse i udskolingen i samfundsfag og dansk.

The aim of the article is to strengthen a democratic and critical approach to Digital Literacy (Digital Myndiggørelse), which is an area of competence in the experimental subject Technology Comprehension in Danish primary schools (grade 1-9), and central to the subject's objective to educate pupils to become "active, critical, and democratic citizens". In the article, we show through an analysis of the current descriptions of the subject, how this competence area is insufficiently developed if pupils are to learn to critically reflect upon the role of technology in society. Therefore, we present theoretical perspectives and practical examples that emphasise a democratic and critical approach to technology comprehension. The conclusion emphasizes the need for pupils of Technology Comprehension to develop an understanding of the complex relationships between technology and society. 


\section{Den teknologisk myndige borger}

\section{- om hvordan kritiske perspektiver på teknologiens rolle i samfundet kan bidrage til teknologiforståelse i folkeskolen}

\section{Indledning}

Baggrunden for indførelsen af forsøgsfaget med teknologiforståelse ${ }^{1}$ i folkeskolen er de forandringer den teknologiske udvikling afstedkommer for rammerne for menneskers liv og samliv i det moderne samfund. I forsøgsfaget teknologiforståelse er det forsøgt med kompetenceområdet digital myndiggørelse at bidrage til, at kommende generationer kan forholde sig kritisk til teknologien og konstruktivt være med til at redesigne den. Eleverne skal ikke bare kunne forholde sig til den enkelte teknologi, men kunne "kritisk reflektere over digitale artefakters betydning for individ, fællesskaber og samfund" (Undervisningsministeriet, 2018a, s. 20), som det hedder i et af de Fælles Mål for det selvstændige fag i udskolingen.

I denne artikel vil vi udfolde og nuancere, hvordan man kan arbejde frem mod dette mål. Når man læser de Fælles Mål for forsøgsfaget, så er målet om myndiggørelse formuleret med underliggende færdigheds- og vidensmål, der leder frem imod at udvikle redesign af digitale artefakter. Men behovet for digital myndiggørelse hænger ikke kun sammen med behovet for at skabe bedre teknologiske løsninger. Det hænger sammen med, at vi skal kunne forholde os til de paradokser, teknologierne skaber, og at disse løsninger ikke altid er teknologiske. Det kunne for eksempel være, når de digitale overvågningsprogrammer, som er udviklet til at skabe sikkerhed, anvendes til at forfølge uskyldige borgere. Derfor argumenterer vi for, at den teknologisk myndige borger i omgangen med nye teknologier ikke blot skal kunne agere myndigt inden for teknologier, men skal kunne forholde sig til teknologier i en samfundsmæssig kontekst. Også når det betyder at vælge løsninger, der ikke er teknologiske - eller at fravælge

1 Den officielle titel for faget er: Forsøg med teknologiforståelse i folkeskolens obligatoriske undervisning. 
teknologier.

Vores arbejde med at videreudvikle forståelsen af digital myndiggørelse i arbejdet med teknologiforståelse i den danske folkeskole er inspireret af en række kritiske stemmer, som har understreget behovet for en mere nuanceret forståelse af digital myndiggørelse. Ove Christensen (2021) argumenterer for, at ud af de fire kompetenceområder i forsøgsfaget, så er det digital myndiggørelse, som er mest mangelfuldt beskrevet. Et interessant bud på en nuancering af forståelsen af digital myndiggørelse er givet af Fibiger, Lorentzen, Hjorth \& Pasgaard (2019), som dog holder sig inden for en designramme, som vi overskrider i vores artikel. Catrine Hasse, Søren Riis og Jesper Balslev (2021, s. 30) argumenterer for, at der er behov for en mere kritisk teknologiforståelse, der indeholder elementer inspireret af teknologivurdering, hvilket vi i andet afsnit af artiklen bidrager til at udfolde. Et omfattende forslag er formuleret af Thomas Illum Hansen (2020, s. 33), der foreslår en skelnen mellem et instrumentelt, et antropologisk, et humanistisk, et naturvidenskabeligt, et didaktisk, et sociologisk og et politisk teknologibegreb. I vores tilgang forsøger vi at forene nye teoretiske perspektiver med perspektiver, som er rodfæstet i folkeskolens fag, såvel som eksisterende praksis i forsøgsarbejdet med teknologiforståelse. Det udelukker ikke, at andre perspektiver på teknologier, såsom humanistiske og naturvidenskabelige, bør have plads i skolen. Artiklen tager derfor udgangspunkt i et behov for at gentænke og diskutere, hvad et begreb for digital myndiggørelse bør indeholde, hvis det skal leve op til det udtrykte ønske om en faglighed, der kan være med til at "danne og uddanne eleverne til at deltage som aktive, selvstændige, kritiske og demokratiske borgere i et digitaliseret samfund" (Undervisningsministeriet, 2018a, s. 8).

\section{En model for analyse af teknologi og design af løsninger}

Centralt i den nuværende beskrivelse af faget er at undersøge den eksisterende teknologis formål og intentioner. Men det giver en snæver fokus på teknologiens oprindelige udvikling, og en sådan analyse vil aldrig føre videre til en forståelse af teknologiens konsekvenser på samfundsniveau og i den kontekst, hvor teknologien skal fungere. Derfor er der brug for at sætte nogle nye begreber på de analyser, som eleverne skal kunne udføre. Nedenstående model har opdelt den digitale myndiggørelse i fire elementer under to overordnede overskrifter. 
Figur 1.

Artiklens bidrag til myndiggørelse i to overskrifter.

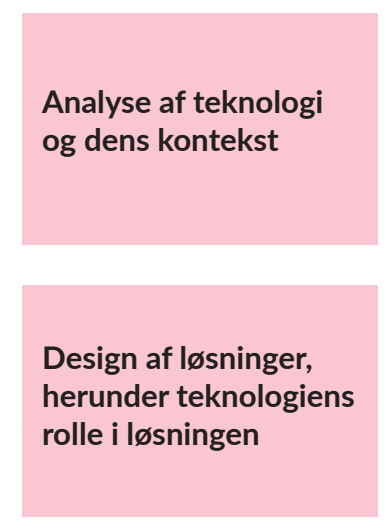

\section{Borgeranalyse \\ 2. Ekspertanalyse}

3. Udvikling gennem fremsyn

4. Udvikling gennem deliberation/samskabelse

Centralt for borger- og ekspertanalyser er at åbne op for forskellige perspektiver for teknologien, så eleverne kan diskutere perspektiver i klassen og derved udvikle en digital myndiggørelse. Fokus flyttes væk fra det enkelte digitale artefakt, og artefaktets indlejrede intentioner, og over mod den måde, teknologien påvirker vores liv og samfund.

Det er de samme principper, som vi ser som centrale, når eleverne skal arbejde med digital myndiggørelse i forbindelse med udviklingen af digitale artefakter. Her bør der arbejdes med elevernes evne til at bringe forskellige perspektiver ind i designprocessen. Ikke bare med henblik på at forbedre et design, men med henblik på en grundlæggende forståelse af de dilemmaer, som udviklingen af ny teknologi kan skabe. Det kunne være, når man skal prioritere mellem borgernes ret til privatliv, firmaernes ønske om overvågning og statens arbejde for sikkerhed, eller mellem en privat borgers udsigt til havet og statens $\emptyset$ nske om at opsætte vindmøller.

Den digitale myndiggørelse skal, i den udvidede forståelse vi foreslår, som teknologisk myndighed give eleverne en forståelse af, hvordan man kan forholde sig til teknologier ud fra forskellige teknologiske og samfundsmæssige perspektiver. Herunder at de kan se hvordan interessekonflikter er iboende i indførelsen af nye teknologier, og hvordan man aktivt kan forholde sig og tage stilling til disse. Nedenstående figur opsummerer, hvordan artiklen forsøger at skubbe og udvide forståelsen af digital myndiggørelse. 
Figur 2.

En udvidet forståelse af digital myndiggørelse.

\section{Den nuværende tilgang}

Fokus på analyse af teknologien, dens oprindelige formål og tekniske potentiale, som er en del af en designproces

\section{En demokratisk tilgang}

Fokus på at forstå teknologiens rolle i samfundet og borgernes muligheder tage stilling og handle i forhold til teknologiens udvikling

\section{Artiklens udfoldelse af modellen}

Artiklen består af tre afsnit. I det første afsnit vil vi redegøre for, hvorfor der er et behov for at genbesøge, hvordan den nuværende forståelse af digital myndiggørelse omsættes til mål i forsøgsfaget. Afsnittet afsluttes med nogle konkrete spørgsmål, som ikke er grundigt udfoldet i den nuværende formulering af digital myndiggørelse. Spørgsmålenes omdrejningspunkt er elevernes mulighed for at udvikle en samfundsmæssig stillingtagen og handleevne i relation til den teknologiske udvikling.

I det andet afsnit udfolder vi teoretiske perspektiver, som kan underst $ø$ tte og udvikle den forståelse af digital myndiggørelse, som artiklen beskriver. Afsnittet tager udgangspunkt i Kant og politisk dannelse og suppleres med aktuelle teoretiske bidrag til en helhedsorienteret forståelse af, hvordan teknologiudvikling og samfundsudvikling hænger sammen. Disse perspektiver er valgt, da de understreger artiklens centrale pointer om digital myndiggørelse, og samtidig trækker tråde ind i de eksisterende fag i folkeskolen, for eksempel samfundsfag, dansk og historie, hvor faglærere vil kunne bidrage til omsætningen af den digitale myndiggørelse i praksis.

For at give konkrete eksempler på redskaber, der kan gøre det muligt at forholde sig til den teknologiske udvikling, viser vi i det tredje afsnit af artiklen, hvordan teknologivurdering og fremsyn kan bruges som ramme for arbejdet $i$ undervisningen: Som alternativ eller supplement til den designorienterede tilgang med fokus på analyse 
og udvikling af digitale artefakter, som allerede findes i forsøgsfaget teknologiforståelse. Artiklen afsluttes med en kort konklusion.

\section{Behovet for at genbesøge rammen for arbejdet med digital myndiggørelse}

Begrebet digital myndiggørelse spiller en væsentlig rolle i forsøgsfaget teknologiforståelse, som et af de fire kompetenceområder, og det fremhæves i flere tekster om faget, at det dermed bidrager til at forberede eleverne til demokratisk deltagelse (Iversen \& Wagner, 2020 s. 8). Men da digital myndiggørelse er et nyt begreb uden en klar definition, så er der en vigtig faglig diskussion om, hvordan det kan forstås og bruges. I det følgende vil vi undersøge, hvordan digital myndiggørelse forstås af nogle af de forskere, der har deltaget i udviklingen af forsøgsfaget, og hvordan det er formuleret i forsøgsfagets læseplan og undervisningsvejledning.

\section{Baggrunden for forsøgsfagets beskrivelse af digital myndiggørelse}

En af de fremmeste fortalere for teknologiforståelsesfagets kompetenceområde digital myndiggørelse er Ole Sejer Iversen. For Iversen er den digitale myndiggørelse indeholdt i det, som han og hans samarbejdspartnere betegner som en designtilgang til teknologiforståelsen (Dindler, Smith \& Iversen, 2019). I designtilgangen skelnes der mellem designprocessen (der indeholder designudfordring, undersøgelse, idéudvikling, konstruktion, argumentation og refleksion) og myndiggørelse (der indeholder værdianalyse, brugsanalyse, formålsanalyse, teknologianalyse, argumentationsanalyse og konsekvensanalyse) (Dindler, Smith \& Iversen, 2019, s. 127). Der er altså tale om både en konstruktion af digitale artefakter og en analyse, hvorigennem eleverne afkoder eksisterende digitale artefakter (Dindler, Smith \& Iversen, 2019, s. 127; Iversen \& Wagner, 2020, 22). Afkodningen af eksisterende digitale artefakter beskrives i teksterne med forskellige begreber: På den ene side er de ovenstående begreber i den bredere analyse centrale, på den anden side fremhæves artefakters indlejrede intentionalitet som det vigtigste: "den digitale myndiggørelse ligger i evnen til at kunne afkode og aflæse de intentioner, som et givet digitalt artefakt kommer med gennem analyse"(Iversen \& Wagner, 2020, s. 22).

Der er denne teoretiske beskrivelse, som er baggrund for forsøgsfagets to led: designproces og analyse. I den faglighed, der er i målbe- 
skrivelserne for forsøgsfaget teknologiforståelse, er designprocesserne og digital myndiggørelse beskrevet på en lidt anderledes måde - analyse og design er koblet tættere sammen i en proces rettet imod redesign, hvilket vi vil redegøre for i det følgende afsnit.

\section{Læseplan}

I Fælles Mål for forsøgsfaget teknologiforståelse er digital myndigg ørelse beskrevet og defineret med inspiration fra den forståelse, der er beskrevet ovenfor fra Iversen og Wagner. Kompetencemålet digital myndiggørelse "Omhandler kritisk, refleksiv og konstruktiv unders $\emptyset$ gelse og forståelse af digitale artefakters muligheder og konsekvenser" (Undervisningsministeriet, 2018b, s. 4). I læseplanen er det beskrevet, hvordan dette skal forstås:

99 Digital myndiggørelse omhandler evnen til analytisk og refleksivt at forstå digitale artefakters betydning i hverdags- og arbejdslivet. Gennem faglige analyser af digitale artefakter, artefaktets indlejrede intentionalitet og artefaktets brug får eleven det nødvendige grundlag for proaktivt at kunne redesigne digitale artefakter, hvor de synes uhensigtsmæssige ift. en given brugspraksis, og til at vurdere artefaktets betydning for individ, fællesskaber og samfund.

(Undervisningsministeriet, 2018a, s. 9)

Der er således to positioner i den digitale myndiggørelse: dels at kunne redesigne og dels vurderingen af artefaktets betydning.

Det er beskrivelsen af digital myndiggørelse i faghæftet for teknologiforståelse som selvstændigt fag, som er udgangspunktet for de mål, der er udvalgt, når teknologiforståelse integreres i eksisterende fag. For alle kompetenceområder gælder, at de har underliggende videns- og færdighedsområder, og det er denne viden og disse færdigheder, der tilsammen udgør kompetencen (dette er den måde, strukturen i viden- færdigheder og kompetencer er formuleret i forhold til den europæiske kvalifikationsramme (EQF)). Videns- og færdighedsområderne for "Digital myndiggørelse" er "teknologianalyse", "formålsanalyse", "brugsstudier", "konsekvensvurdering" og "redesign" (Undervisningsministeriet, 2018b, s. 11). De første tre analysekategorier er rettet mod de "digitale artefakter" og deres formål og brug. Det er det fjerde område "konsekvensvurdering", hvori der indgår, at eleven kritisk kan "reflektere over digitale artefakters betydning for individ, fællesskaber og samfund" (Undervisningsministeriet, 2018b, s. 11). Der 
ligger dog stadig den implicitte begrænsning, at denne konsekvensvurdering hænger sammen med de øvrige områder, og er rettet imod "redesign". Dermed er muligheden for en bredere samfundsmæssig analyse indskrænket. At hensigten er at arbejde frem mod et redesign fremgår også af læseplanen:

99

Digital myndiggørelses kompetencegivende elementer i teknologiforståelsesfagligheden er tofoldigt. Gennem digital myndiggørelse får eleverne et fagligt fundament for at bedømme eksisterende digitale artefakter gennem faglige og strukturerede analyser. Desuden styrker digital myndiggørelse elevernes evne til at omsætte egne analyser til et redesign af uhensigtsmæssige digitale artefakter. Gennem digital myndiggørelse erhverver eleverne således en forståelse af og en evne til at forandre uhensigtsmæssige digitale artefakter ift. eget liv, fællesskab og samfund.

(Undervisningsministeriet, 2018a, s. 10)

Som det fremgår, så skal eleverne bedømme eksisterende digitale artefakter, omsætte analyser til redesign og det, der kommer ud af det, er en "evne til at forandre uhensigtsmæssige digitale artefakter". Dermed er det også tydeligt, at den digitale myndiggørelse i forsøgsfaget teknologiforståelse er snævert knyttet til analyse og redesign af digitale artefakter. Dette kan være, og er sikkert, gode og nyttige elementer i en demokratisk omgang med teknologier, men det er begrænsende i forhold til det dannelsesmål, der er formuleret for faget. I måloversigten for faget er progressionen for kompetenceområdet beskrevet som følgende:

Figur 3.

Kompetencemål for digital mynddiggørel-

se, forsøgsfaget teknologiforståelse.

Kompetencemå

Digital myndiggorelse

Omhandler kritisk refersiog

undersogelse og forst telse of divitile

undersogelse og forstáelse af digitale

Indskoling Eleven kan beskrive digitale artefakter i sin
hverdag og handle hensigtsmessigt i sit mød

\begin{tabular}{|l} 
Eeleven kan vurdere digitale artefakters \\
intentionalitet og anvendelsesmuligheder
\end{tabular} intentionalitet og anvendelsesmuligheder
med henblik pà at kunne handle reflekteret med henblik pa at kunn
i konkrete situationer 
Målet om, at eleverne i udskolingen kan handle med dømmekraft i komplekse situationer, der vedrører digitale artefakters betydning for fællesskab og samfund, taler direkte ind i væsentlige samfundsfaglige og demokratiske problemstillinger. Men analyserne, som er beskrevet i læseplanen, har ikke fokus på at udvikle elevernes forståelse af samfundsmæssige dilemmaer som et mål i sig selv, men er i stedet koncentreret om det enkelte artefakts formål, intention, brug og muligt redesign.

\section{Forskellen mellem det selvstændige fag og integrationen i eksisterende fag}

I det ovenstående har vi set på den overordnede forståelse af digital myndiggørelse, som den er skrevet ind i forsøgsfaget teknologiforståelse som selvstændigt fag. Hvis man undersøger, hvordan digital myndiggørelse er skrevet ind i de eksisterende fag som en del af forsøget, er det kun i samfundsfag og dansk, at det er skrevet direkte ind. I dansk er det skrevet ind under kompetenceområdet kommunikation, efter 6 . og efter 9. klassetrin. Her skal man arbejde med mål om digital myndiggørelse og digital sikkerhed. I matematik, hvor teknologiforståelse er sit eget kompetenceområde, er digital myndiggørelse skrevet ind mere indirekte gennem mål om brugsstudier og redesign. I naturfagene er der ikke skrevet mål ind, som omhandler digital myndiggørelse. I samfundsfag er digital myndiggørelse skrevet ind som et nyt kompetenceområde. Det giver en udfordring, idet faget dermed tilføjes et helt nyt kompetenceområde, som skal udfoldes inden for fagets begrænsede ressourcer (almindeligvis 2 timer om ugen).

Den nuværende struktur for integrationen af digital myndigg $\emptyset$ relse i de eksisterende fag sætter derfor rammer for, hvordan målene for kompetenceområdet tænkes at skulle udfoldes i de forskellige fag. Det er et problem, at der er tilføjet ekstra indhold til fagene, uden at andet indhold er fjernet, og målene er ikke nødvendigvis tænkt sammen med målene fra de eksisterende fag. Da digital myndiggørelse tænkes integreret primært i dansk og samfundsfag, ville det derfor styrke beskrivelsen af kompetenceområdet, hvis den relateres bedre til de fag. I denne artikel vægtes en samfundsfaglig inspiration, da samfundsfagligheden kan levere væsentlige samfundsmæssige perspektiver til at leve op til målsætningen i forsøgsfaget om at arbejde med konsekvensvurdering på samfundsniveau. 


\section{Digital myndiggørelse som en refleksiv designproces}

Som vi har vist i ovenstående afsnit, så er den digitale myndiggørelse i forsøgsfaget knyttet til analyse og redesign af digitale artefakter. Herved opstår en forståelse af myndiggørelse, der er knyttet til den enkelte teknologi. Forståelsen af myndiggørelse i forsøgsfaget kan ses som et ekstra refleksivt led på designprocessen, således at hvert led i designprocessen kan understøttes af en analyse. Vægten i digital myndiggørelse ligger på designerens intention ved udviklingen af teknologien. Spørgsmålet er, om udviklingen af teknologien, eller de efterfølgende konsekvenser teknologien kan få, bør analyseres eller forstås alene ud fra teknologien i sig selv. Det, som ikke bliver tydeligt i beskrivelsen, er, hvornår der tages diskussioner, som ikke nødvendigvis knytter sig til den enkelte teknologi, men i stedet den kontekst teknologien skal fungere $\mathrm{i}$.

Artiklen vil derfor udfolde, hvorfor konteksten for teknologiudvikling er en væsentlig faktor for at forstå både hvordan og hvorfor teknologi udvikles, men også hvilke konsekvenser teknologien kan få. Det kunne være diskussioner af de samfundsmæssige rammer, der udvikler og begrænser teknologien, og hvordan man kan være med til at forme dem. I princippet ligger der muligheder for en bred samfundsmæssig forståelse af teknologier i arbejdet med brugsanalyse og konsekvensanalyse, men beskrivelserne i læseplanen giver ingen bud på, hvordan man nuancerer analyserne og løfter blikket op fra arbejdet med en enkelt teknologi i en konkret designproces.

Digital myndiggørelse bør være en del af en demokratisk dialog, hvor man skal turde stille spørgsmål, der også går udover den konkrete teknologi. Det er denne type spørgsmål, som ikke er tydeligt udfoldet i beskrivelsen af det nuværende fag, og som det vil være interessant i højere grad at adressere, hvis kompetenceområdet skal genbesøges. Det kan være spørgsmål som:

— Hvad betyder konteksten for de værdier, der indlejres i teknologien, og de tekniske muligheder for at udvikle teknologien?

— Er teknologi den rigtige løsning eller er der brug for noget helt andet?

— Kan teknologien påvirke andre end de brugere, den er målrettet til?

— Kan der opstå nye negative påvirkninger fra teknologien, når den bruges i stor skala?

— Bør visse borgere have en privilegeret adgang til at påvirke udviklingen og redesign af teknologien? 
Spørgsmålet er, hvorfor det er så vigtigt at lære noget om disse spørgsmål for eleverne i fremtidens folkeskole? Det følgende teoretiske afsnit udfoldes centrale elementer i forståelse af myndighed og betydningen af teknologi på samfundsniveau, som kan føre os videre til forståelsen af vores rolle i og indflydelse på teknologiens udvikling.

\section{Den teoretiske inspiration for en myndiggørende tilgang til teknologiens rolle i samfundet}

Hvis undervisningen skal være rettet imod en teknologisk myndighed, som vi foreslår i denne artikel, er en række teorier og samfundsanalyser oplagte at trække på som baggrund for denne forståelse. Teorierne sætter fokus på forholdet mellem teknologi og samfund, samt de løbende kampe, der foregår, for at definere teknologiens rolle i samfundet. Afsnittet tager udgangspunkt i Kants forståelse af myndighed, som understreger behovet for myndiggørelse i et demokrati. Herefter beskrives nyere teorier, som fremhæver vigtigheden i, at den digitale udvikling løbende gøres til genstand for diskussion og refleksion; en refleksion som går ud over analysen af det enkelte digitale artefakt til at forstå samfundsmæssige sammenhænge.

\section{Den myndige borger - Kant og den politiske dannelse}

Den formulering af myndighedsbegrebet, der danner grund for forståelsen af myndighed i moderne pædagogik og politisk filosofi stammer fra Kants berømte besvarelse af spørgsmålet: Hvad er oplysning? Her skriver han, at "Oplysning er menneskets udgang af dets selvforskyldte umyndighed. Umyndighed er manglen på evne til at bruge sin forstand uden en andens ledelse" (Kant, 1999). Myndighed er således forbundet med oplysning, og at man kan bruge sin fornuft og ikke er underlagt andre.

Kants begreb om myndighed danner bl.a. grund for den tyske tradition for politisk dannelse. Det tyske selskab for politisk dannelse (GPJE) formulerede politisk myndighed som det overordnede mål for den politiske dannelse. Politisk myndighed er delt op i tre områder: politisk dømmekraft, politisk handleevne og metodiske færdigheder (A. S. Christensen, 2017, s. 67; Detjen, Kuhn, Massing, Richter, Sander \& Weißeno, 2004, s. 13). Den politiske dømmekraft omhandler at 
kunne tage stilling til politiske og samfundsmæssige spørgsmål. Den politiske handleevne vedrører at kunne handle på den viden, man har. De metodiske færdigheder vedrører den faglighed, der skal til, og som læres i skolen med henblik på at opnå denne dømmekraft og handleevne. Hvis man ser digital myndiggørelse som en del af en bredere politisk dannelse, er det relevant at undersøge, hvilke kompetencer der skal til for at kunne udvikle en politisk dømmekraft i forhold til udvikling af teknologi.

Den politiske handleevne kunne være formuleret ind i teknologiforståelsesfaglighedens begreb om teknologisk handleevne. I faghæftet hævdes det, at "Gennem de konstruerede og kritiske elementer af myndiggørelse, af designprocesforståelse, af computationel tankegang og af teknologisk handleevne rummer fagligheden også et frigørende element, som sætter eleven i stand til at forandre i verden med digital teknologi" (Undervisningsministeriet, 2018a, s. 9). Men den teknologiske handleevne er begrænset til handlinger inden for teknologien. Kompetencemålet er formuleret således for udskolingen: "Eleven kan vurdere, vælge og på kvalificeret vis anvende digitale teknologier i autentiske situationer" (Undervisningsministeriet, 2018a, s. 13).

I forhold til brugen af myndiggørelsesbegrebet er det værd at se på, hvordan begrebet empowerment har været oversat indenfor politologien. For at fange den dobbelte betydning af det engelsksprogede begreb har man på dansk anvendt to begreber. Myndiggørelse, der dækker den subjektive side af empowerment, at man har den viden og de færdigheder, der skal til for at kunne deltage i en proces, og mægtiggørelse, der betegner, at der er strukturer til stede, der gør det muligt for den enkelte at handle (J. G. Andersen, 2004, s. 24). I forhold til begrebet om myndiggørelse i forsøget med teknologiforståelse kunne man på samme måde tale om, at der er en subjektiv side, der vedrører at have evner og viden (i dette tilfælde om teknologier) og så den objektive side, mægtiggørelse, der vedrører de samfundsmæssige strukturer, der gør det muligt at handle i forhold til teknologien. I læseplanen er det angivet som et "frigørende element" i myndiggørelsen, at alle elever får lige adgang til at "mestre digitale teknologier, som på indgribende og radikal vis påvirker vores liv, vores fællesskaber og vores samfund" (Undervisningsministeriet, 2018a, s. 9). Udfordringen er, om eleverne kan forholde sig til de økonomiske og politiske strukturer, der betinger denne teknologiske udvikling. Det er muligt, at eleverne lærer at mestre teknologierne, men som det fremgår af den citerede sætning ses både vores liv, vores fællesskaber og vores samfund som (passive) objekter for de teknologier, som påvirker os.

Digital myndiggørelse kan derfor udvides med overvejelser om, hvordan vi kan handle i relation til teknologiens rolle i vores hverdag og samfund. Som Pötzsch beskriver det i sin refleksion over Critical 
Digital Literacy: “[P]upils and students should learn to critically reflect upon and properly contextualise technologies that have enormous implications for their lives not only as future part of a work force but also as citizens and fully-fledged individuals" (2019, s. 221). Vi skal altså ikke bare uddanne eleverne til at kunne analysere teknologi, som en del af en designproces, men også danne fremtidens borgere til en kritisk stillingtagen til teknologiens rolle i samfundet.

\section{Teori om digitale teknologiers betydning for individ, fællesskab og samfund}

Skolefagene rummer allerede muligheder for en bredere forståelse og analyse af teknologiers menneskelige og samfundsmæssige konsekvenser, men uden at det er udfoldet. Faghæftet for forsøgsfaget teknologiforståelse i samfundsfag beskriver, at teknologianalysen (brugerundersøgelser og konsekvensvurderinger) skal inddrage sociologiske, $\emptyset$ konomiske og politiske aspekter af teknologis betydning for vores liv. Betydningen af dette er ikke udfoldet, og det er kun i begrænset omfang beskrevet i de forløb, der er udviklet til afprøvning i skolen.

I det følgende vil vi skitsere, hvordan sociologiske, økonomiske og politiske/demokratiske perspektiver kan være komponenter i en digital myndiggørelse.

Sociologiens fædre understregede en bekymring for, at ny teknologi og arbejdsforhold skabte negative konsekvenser for en række grupper i samfundet. Emile Durkheim beskrev, hvordan arbejdsdelingen i samfundet, der var betinget af den teknologiske udvikling, førte til funktionel differentiering i samfundet, som igen førte til, at nye solidaritetsformer opstod og andre forsvandt. Hos Durkheim er dette beskrevet med begrebet organisk solidaritet, der i de industrialiserede samfund afløser de traditionelle samfunds mekaniske solidaritet (Durkheim, 2000; Møller, 2019, s. 285). Karl Marx beskriver, hvordan den teknologiske udvikling fører til en fremmedgørelse for arbejderen, der ikke har nogen relation til det produkt, han er med til at fremstille, fordi han blot er en lille brik i et stort maskineri. Det forstås bogstaveligt hos Marx, der beskriver hvordan arbejderen "bliver et rent og skært tilbehør til maskinen, og der kræves kun det mest enkle ensformige greb, der kan læres på et øjeblik”(Marx \& Engels, 1976, s. 22). Teknologiens rolle har i hverdagen og samfundet derfor været undersøgt længe, og en række aktuelle teorier følger op på de tidlige indsigter.

Teknologiudviklingens betydning for fællesskaber er hos nyere sociologer taget op af blandt andre Anthony Giddens. Giddens (1994, s. 79). Han betoner nødvendigheden af tillid til ekspertsystemer, netop 
i det højtudviklede og differentierede samfund må vi som individer have en vis tillid til, at systemerne fungerer. Hvis vi begynder at stille spørgsmål til, om en flyvemaskine egentlig er bygget ordentligt, fordi vi ikke forstår den, kommer vi ikke langt. Spørgsmålet er så, hvilken grad af tillid og forståelse af teknologier, der er nødvendig for at udvikle tillid, og hvilke former for stillingtagen og kritik er der rum for i det senmoderne samfund.

En anden aktuel sociolog, der tager tråden fra Marx' begreb om teknologiens fremmedgørende konsekvenser op, er Hartmut Rosa. Rosa beskriver, hvordan den teknologiske acceleration, der kommer til udtryk i for eksempel computerens forøgede datakraft, har ført til en social acceleration. Det kan synes ulogisk - hvis vi kan producere mere, og mere effektivt burde vi jo få mere tid - men hvis man i 1990 modtog 10 (fysiske) breve i løbet af en dag, som man brugte to timer i alt på at svare på, modtager man i dag måske 70 e-mails, som alle skal besvares (Rosa, 2014, s. 30). Resultatet er, for Rosa, et accelerationskredsløb, hvor den teknologiske acceleration medfører en acceleration af social forandring, som igen fører til en acceleration af 'livstempoet' (Rosa, 2014, s. 40). Rosas forskning understreger, at der er en sammenhæng mellem det økonomiske system, der tilskynder til, og muliggør vækst i materiel produktion, og forandringer af sociale relationer såvel som menneskets forhold til naturen. I den sammenhæng peger Kate Raworth (2017) på behovet for helt at gentænke vores forhold til teknologien og til økonomiens fundament i en bæredygtig retning.

Internettet er en vigtig infrastruktur for den digitale teknologi, som påvirker både vores hverdag og samfund. I sin bog Overvågningskapitalismens tidsalder (Zuboff, 2019) beskriver Soshana Zuboff de senere års udvikling indenfor 'Big Tech', hvor teknologiske mastodontvirksomheder har opnået monopolagtig status og er i stand til at dominere og bestemme retningen for den teknologiske udvikling (Google Microsoft, Apple, Amazon og Facebook). Især fremhæver hun deres brug af 'big data' som et problem, som er den adfærdsdata virksomhederne indsamler. Industrisamfundets vareproduktion var kendetegnet ved, at der var nogen, der producerede en vare andre kunne købe og forbruge. I overvågningskapitalismen er det data, der er den gyldne ressource. Og i særdeleshed data om forbrugeres adfærd. Google startede som en søgemaskine, der kunne hjælpe med at finde informationer på internettet, men i dag er det en virksomhed, der lever at samle adfærdsdata. Perspektiverne $i$ at bruge data - til gode og mindre gode formål - er næsten uendelige, fra at præsentere de bedste tilbud til Black Friday, til at målrette politiindsatser til områder, hvor det kan formodes, at kriminalitet vil finde sted, eller lave personaliseret sundhedsbehandling. Spektakulære eksempler på, hvordan data om vælgere kan misbruges, som dokumenteret i Cambridge Analyti- 
ca-skandalen, vækker opmærksomhed. Men lokale politikeres brug af Facebook er også noget, som vi som borgere skal kunne gennemskue, hvis vi skal kunne deltage som myndige borgere.

Ovenstående teoretiske overvejelser og aktuelle eksempler fra sociologi, økonomi og politik kan inspirere til at flytte fokus væk fra en digital myndiggørelse med primær fokus på designprocesser og digitale artefakter mod et fokus på samspillet mellem teknologi, mennesker og samfund. Eksemplerne viser, at hvis man ønsker, at skoleelever kan handle som myndige borgere i forhold til den teknologiske udvikling, må en digital myndiggørelse indeholde refleksioner, både om hvordan teknologiudviklingen påvirker alle aspekter af samfundet og menneskenes indbyrdes forhold, og hvordan menneske og samfund kan tage kontrol over den teknologiske udvikling. Dette indebærer viden om digitale artefakter og deres design, men det indebærer også nødvendigvis viden om forholdet mellem menneske, teknologi og samfund.

\section{Praktisk inspiration til en ny digital myndiggørelse i folkeskolen}

Afsluttende vil vi se på de tilgange og metoder til vurdering af teknologiers konsekvenser, som er udviklet under overskrifterne teknologivurdering og fremsyn. Her kan findes inspiration til konkrete måder, som man kan arbejde demokratisk med udvikling af teknologi. Det vil sige, at fokus flyttes væk fra en eller flere designeres udvikling af digitale artefakter, som er rammen for det nuværende fag, over mod et fokus på fællesskabets ønsker og behov for den teknologiske udvikling.

\section{Teknologivurdering og fremsyn som eksempler på metoder, som fremmer en demokratisk tilgang til teknologiforståelse}

De ovenstående teoretiske afsnit har understreget, hvordan teknologiens rolle i samfundet konstant udvikles og forhandles. Forståelse af digital myndiggørelse bør derfor både inkludere overordnede perspektiver på teknologiens rolle i samfundet, ligesom den bør inspireres af metoder til teknologivurdering, som forsøger at fremme demokratiske metoder til at bestemme teknologiens risici og rolle.

Udover at drage inspiration fra viden om teknologi indenfor forskellige samfundsfaglige discipliner, så kan et kommende fag $\mathrm{i}$ 
folkeskolen med fordel drage på den viden, der eksisterer med at vurdere teknologiers potentialer og risici på tværs af vidensfelter og samfundets interessenter. Teknologiforståelsesfaglighedens forståelse af, hvordan elever kan blive digitalt myndiggjorte og udvikle teknologisk handleevne er begrænset til den valgte ramme, som tager udgangspunkt i designtænkning som proces for alle forløb. Hvis man lader sig inspirere af erfaringer med teknologivurdering ${ }^{2}$ er der muligheder for at have sammenhængende vurdering af teknologiers menneskelige og samfundsmæssige betydning (se P. D. Andersen \& Rasmussen, 2012).

Gennem årene er der udviklet en række praktiske metoder til at vurdere potentiale og risici i forbindelsen med udviklingen og anvendelsen af teknologier, hvilke ofte betegnes under overskrifterne teknologivurdering eller fremsyn. I Danmark har der været arbejdet særligt med at udvikle teknologivurdering med fokus på borgerinddragelse (se for eksempel I.-E. Andersen \& Jæger, 1999; Hagendijk \& Irwin, 2006).

Rafael Popper (2008) har forsøgt at samle et overblik over de mange forskellige metoder, der anvendes rundt omkring i verden til teknologivurdering og fremsyn ${ }^{3}$. Overblikket fremhæver, at metoderne kan opdeles ud fra, i hvor høj grad de bygger på forskellige videnskilder. Eksperter og evidens anvendes til at underbygge processerne med videnskabelig viden. Interaktion mellem forskellige aktører og anvendelse af kreative processer anvendes til at give processerne legitimitet og sikre, at forskellige løsninger er tænkt igennem. Videnskilderne er uddybet kort herunder. Arbejdet med teknologivurdering kan altså både give os nogle guidelines for, hvilke temaer der bør arbejdes med i teknologiforståelse, men også nogle praktiske metoder, som der kan arbejdes ud fra i den konkrete undervisning.

\section{Ekspertise og evidens som grundlag for teknologivurdering}

Ekspertise og evidens spiller altid en større eller mindre rolle i teknologivurdering og er essentielt for at forstå teknologiens konsekvenser for samfundet. Men det kommer med et dilemma. På den ene side har vi behov for ekspertise for at nå frem til løsninger, og på den anden

2 Teknologivurdering kan defineres som metoder og tilgange til at undersøge samfundsmæssige konsekvenser af teknologi med henblik på at informere beslutninger eller den offentlige debat. For en uddybning af definitioner se Decker og Ladikas (2004).

3 Der er et væsentligt overlap mellem metoder til fremsyn og teknologivurdering, men fremsyn kan defineres som: "en systematisk, fremtidsorienteret, analytisk og participatorisk proces, der dels bidrager til fælles billeder af langsigtede udviklinger inden for forskning, teknologi, erhvervsliv og samfundet i almindelighed, og dels bidrager til samarbejde mellem relevante aktørgrupper om en ønskelig udvikling igennem fælles strategier, beslutninger og handlinger" (P. D. Andersen \& Rasmussen, 2012). 
side vil ekspertise altid blive kritiseret for ikke nødvendigvis at føre til de bedste løsninger (Nowotny, 2003). Både med inddragelse af ekspertise og evidens vil der altid opstå spørgsmål, om det er den rigtige evidens eller den rigtige ekspertise. I nogle tilfælde vil det være borgere eller brugere, som måske ved mest om, hvordan teknologien vil blive brugt, der ikke bliver hørt. Derfor forsøger man ofte i teknologivurdering at løse denne udfordring gennem borgerinddragelsesprocesser (se eksempelvis Nowotny, 2003) og hos firmaer gennem brugerinddragelse (se eksempelvis Hippel, 2005). Fremtidens borgere bør derfor kunne forholde sig til centrale spørgsmål i relation til ekspertise. Hvordan udvikles ekspertise? Hvorfor er eksperter uenige? Hvornår kan de selv som børn og borgere bidrage med vigtig viden?

\section{Interaktion mellem aktører og kreative processer}

Teknologiudviklingen afhænger af ekspertise, men det giver også nogle særlige muligheder for at vurdere potentialer og risici, når forskellige eksperter bliver sat sammen, eller når eksperter interagerer med borgere eller brugere. Således kan borgere være eksperter i, hvordan en bestemt teknologi bliver anvendt i hverdagen, og de kan derfor komme med vigtige input. Men den type processer sker ikke automatisk, men skal opfindes og faciliteres fra gang til gang. Heldigvis er der masser inspiration at hente i tidligere erfaringer, hvor man har underbygget beslutninger med omfattende inddragelsesprocesser (se eksempelvis P. D. Andersen \& Rasmussen, 2012; Popper, 2008). Forskellige former for spil og scenarier bliver anvendt til at illustrere, at der er forskellige mulige fremtider med hver deres konsekvenser. Gennem fremsynsprocesser kan der skabes en dialog om, hvilke ønsker forskellige deltagere har for fremtiden og dermed for den teknologiudvikling, der skal føre os derhen (se eksempelvis Rasmussen, Andersen \& Borch, 2010). Det, at kunne tænke kreativt, er derfor vigtigt, når man skal overveje den rolle, digitale artefakter skal have i samfundet.

Ovenstående gennemgang af videnskilder indenfor teknologivurdering og fremsyn kan give os en idé om, hvilke forskellige tilgange som er relevante at trække på for et kommende fag, hvis det i højere grad skal vægte en forståelse af teknologiens rolle og konsekvenser i samfundet. Det fører os tilbage til figuren med de fire tilgange udviklet i artiklen, som udfoldes yderligere herunder. 
Figur 1.

Artiklens bidrag til myndiggørelse i to overskrifter.

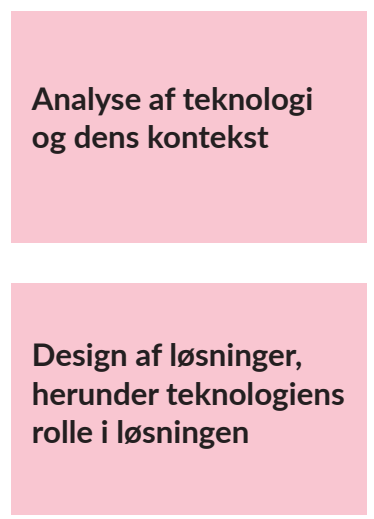

1. Borgeranalyse

2. Ekspertanalyse

3. Udvikling gennem fremsyn

4. Udvikling gennem deliberation/samskabelse

Afsluttende vil vi se nærmere på, hvordan digital myndiggørelse, som beskrevet i denne artikel, kan udføres i praksis. Vi har forsøgt at beholde en simpel ramme for arbejdet med den digitale myndiggørelse, som beskrevet i modellen ovenover, så målsætningerne er realistisk for et fag af en endnu ikke defineret størrelse i folkeskolen. Ligeledes er vi inspireret af lovende praksis fra forsøgsfaget, der har skubbet faget i retning af de målsætninger, som er fremhævet i artiklen. Med inspiration i litteraturen om teknologivurdering og fremsyn, så kunne to typer af analyser være interessante:

\section{Borgeranalyse}

Designprocesser tager ofte udgangspunkt i en brugeranalyse, hvor man ser nærmere på brugerens behov. I et myndiggørelsesperspektiv er det vigtigt at understrege, at teknologien kan komme til at påvirke flere end den konkrete brugergruppe, som den er udviklet til. Det handler om at åbne deres øjne for, at vores samfund består af mange forskellige interesser, og at teknologien ofte er udviklet til et begrænset antal målgrupper.

I forløbet Min mobiltelefon (Kiær, 2020) skal eleverne i 1. klasse forholde sig til, hvordan mobiltelefoner er med til at påvirke kommunikation mellem mennesker. Mobiltelefoner er en interessant teknologi at tage udgangspunkt $i$, fordi den lige nu er allestedsnærværende i elevernes hverdag. Eleverne har nok også selv erfaringer med både hensigtsmæssig og uhensigtsmæssig brug af teknologien, hvilket er med til at skabe interesse. I mange klasser har man regler for mobil- 
telefoner, så her har eleverne måske allerede skullet forholde sig til, hvordan teknologien påvirker deres egen læringskontekst i skolen. Det skaber en interessant ramme for diskussioner af teknologien, som kan gå ud over individ-niveauet og få eleverne sig til at forholde sig til mere komplekse kontekster.

I de større klasser kan det antages, at eleverne har langt mere kendskab til digitale teknologier, som de anvender flittigt både i skolen og udenfor. Derfor kan der tages udgangspunkt i mere komplekse emner, som for eksempel konsekvenserne af Google som en altoverskyggende søgemaskine, herunder den algoritme der er styrende for resultaterne af en søgning. Det arbejder eleverne med i forløbet: "Kender Google din type?" (A. S. Christensen \& Møller, 2020). Ligesom mobiltelefonen er Googles platform en teknologi, som er relevant for elevernes hverdag, men som samtidig kan sættes i et nyt perspektiv gennem en undersøgende tilgang. En borgeranalyse tilgang kan åbne op for en diskussion af teknologiens konkrete brug, men også samfundsmæssige diskussioner af sikkerhed, overvågning og demokrati, som ikke relaterer sig direkte til vores daglige brug af teknologien. Hermed kan det nuancere brugeranalyse i det nuværende forsøgsfag, som har fokus på brugernes input til udvikling af digitale artefakter.

\section{Ekspertanalyse}

En anden type analyse er ekspertanalyse, hvor eleverne ser på teknologiers potentialer og konsekvenser gennem eksperter, der har arbejdet med teknologien eller lignende teknologier. Denne type analyse kan gå mere i dybden med for eksempel de tekniske eller økonomiske aspekter af teknologien, og derved åbne elevernes forståelse af kompleksiteten $\mathrm{i}$ at udvikle og tilpasse teknologien til forskellige behov. Samtidig vil det kunne give eleverne et indblik i eksperternes forskellige syn på teknologierne. Det vil derfor også kunne give diskussioner af, hvad ekspertise er, og hvilken rolle ekspertise spiller i den offentlige debat.

Ekspertanalyse kunne derfor tage udgangspunkt i nogle af de samme emner som borgeranalysen, men med en lidt anden vinkel. I forsøget med teknologiforståelse arbejder eleverne i forløbet "ElevAula” (Køhrsen, Andersen, Caprani, Christensen \& Hejsel, 2020) med at komme med et forslag til re-design af Aula. Aula er en kommunikationsplatform brugt af mange skoler. I forløbet anbefales, at den lokale Aula-administrator inddrages med henblik på at give eleverne viden om den lokale brug af Aula samt eventuelt feedback på deres redesign. Netop inklusionen af den type eksperter vil give eleverne et nuanceret indblik i, hvordan teknologien er blevet udviklet og diskutere teknologiens uhensigtsmæssigheder. De vil også kunne give deres bud på, hvordan platformen bedst kan anvendes og tilpasses til deres skoles behov. 


\section{Design gennem fremsyn}

En interessant måde at sætte teknologier i perspektiv er gennem forskellige former for fremsyn. Her er formålet ikke at forudsige fremtiden, men at forsøge at opstille scenarier for de mest ønskværdige fremtider. At skabe en historie om fremtiden er med til at åbne op for kreativitet, og man kan så efterfølgende snakke om, hvilke muligheder de nuværende teknologier giver og ikke giver. Den nye kontekst, man skaber gennem historierne, er med til at sætte vores egen kontekst i perspektiv og kan derigennem skabe væsentlige diskussioner om, hvilke værdier vi vægter højest.

Lad os illustrere det med et eksempel, som omhandler demente ældre. Som forsøgsfaget er præsenteret nu, så vægtes det at arbejde med konkrete teknologier. Hvis eleverne bliver sat til at beskæftige sig med demente ældre, så kan de hurtigt begynde at tænke på teknologiske løsninger, der kan hjælpe i hverdagen (se eksempelvis Fougt \& Philipps, 202O, s. 45). Men gennem fremsyn får teknologi en helt anden rolle, hvilket nedenstående eksempel viser. For hvad er egentlig vigtigt for ældres liv? Fremtidsværkstedet er en metode til fremsyn. I et fremtidsværksted arbejdes typisk med tre faser (Jungk \& Müllert, 1989). I den første fase arbejdes kritisk med den nuværende situation med henblik på at definere væsentlige problemstillinger. I næste fase arbejdes kreativt med idéer for fremtiden og i sidste fase arbejdes med, hvordan de bedste idéer kan realiseres. Et eksempel fra Jungk og Müllert (1989) er et fremtidsværksted om overvågningsteknologi i sygehuse. Her blev resultatet et nyt design af sygehuset, som et menneskenært borgersygehus, hvor der ikke er behov for computerstyrede alarmer.

En række forløb i det nuværende forsøgsfag bruger på forskellig vis fremtiden, eller mulige fremtider, til at skabe perspektiver på vores forhold til teknologi. Det gør for eksempel "Vores digitale fremtidsby" (Binggeli, Frydendahl, Hansbøl, Klausen \& Søgaard, 2020), "Kan man være ven med en robot?" (Godtliebsen, Nielsen, Kiær, Lorentzen \& Nissen, 2020) og "Overvågning i skolen i år 2030" (Nielsen, Godtliebsen, Kiær, Lorentzen \& Nissen, 2020). Forløb som disse kan flytte fokus væk fra den enkelte teknologi og sætte fokus på, hvilken rolle vi $\emptyset$ nsker, at teknologien skal spille i vores liv.

\section{Design gennem deliberation/samskabelse}

Det sidste punkt omhandler at sikre en bred inddragelse, når man arbejder med teknologi. I den nuværende beskrivelse af forsøgsfaget, så skal eleverne arbejde med at redesigne teknologierne, og derved påvirke deres design og brug. Men en stor del af de teknologier, der omgiver os, er enten for komplekse til, at vi selv kan tilpasse dem eller i højere grad har brug for nye måder at bruge dem på. Et eksempel er 
brugen af mobiltelefoner i klassen, hvor nogle klasser har valgt efter en fælles diskussion at låse mobilerne inde i et skab. Løsningen på forstyrrelserne fra mobiltelefonen har altså været en ændret adfærd i stedet for et redesign af selve teknologien. Den måde at tage fælles ejerskab over brugen af en teknologi er derfor en anden måde at tilpasse teknologien, som også bør tænkes ind i teknologiforståelse gennem en forståelse af deliberative processer. Med telefonen i klasseværelset påvirker teknologien ikke bare den enkelte bruger, og derfor bliver det nødvendigt med en fælles diskussion af teknologiens brug.

I designprocesser arbejder man ofte med brugerinddragelse med henblik på at optimere det digitale artefakt, som man er ved at udvikle, men hvis blikket løftes fra den enkelte teknologi, så får vi en anden type inddragelse. Gennem bredere inddragelsesprocesser kan man arbejde med de forskelligartede konsekvenser af teknologi og på den måde nærme sig målet om konsekvensanalyse på samfundsniveau. Eleverne kan lære at facilitere små processer, som ikke bare har til formål at optimere teknologien, men også diskutere brugen af teknologien og værdien af analoge alternativer. Herigennem kan eleverne få øje for de forskellige perspektiver på teknologier, og kan bidrage til overvejelser om, hvilken vægt forskellige perspektiver skal have.

\section{Konklusion}

En af målsætningerne i de Fælles Mål til forsøgsfaget er, at elevernes skal kunne arbejde med konsekvensvurdering på et samfundsniveau i udskolingen, hvilket både er et relevant og ambitiøst mål. Men vejen frem til dette mål er ikke tydelig. I artiklen har vi argumenteret for, at den nuværende forståelse af digital myndiggørelse er for snævert knyttet til design og redesign af digitale artefakter. Denne tilgang bidrager med vigtige kompetencer til udvikling af digitale artefakter, men giver ikke eleverne den nødvendige forståelse af sammenhængen mellem teknologi og samfund, ligesom den ikke bidrager til elevernes kompetence $i$ at deltage demokratisk $i$ at forholde sig til og forme teknologiernes rolle i vores samfund.

Kompetenceområdet digital myndiggørelse har behov for udvikling og nuancering. Indtil nu har det været begrænset med konkrete forslag til tilpasninger af kompetenceområdet. Artiklens bidrag er derfor at foreslå en ny ramme for, hvordan digital myndiggørelse kan udvikles og omsættes med større blik for sammenhængen mellem teknologi og samfund. Tilgangen kalder vi den teknologisk myndige borger og er bygget op om en simpel model med fire konkrete tilgange. Tilgangene understreger behovet for at analysere teknologiens rolle 
i samfundet både set fra borgere og eksperter, så vi forstår, hvilken betydning den har i vores og andres liv. Derudover understreger den behovet for mestring af facilitering af kreative og inddragende processer, så forskellige perspektiver bliver inddraget i udviklingen af ny teknologi.

Hvis man skal udvikle teknologiforståelse i en skolesammenhæng, og målet er en reel dannelse af aktive og kritiske borgere, så bør man forholde sig til, om den nuværende forståelse af digital myndiggørelse er dækkende. Vi er opmærksomme på, at en mere nuanceret forståelse af myndiggørelse også vil stille krav til de lærere, som skal omsætte det til praksis. Her tænker vi, at man med fordel kan trække på lærere fra for eksempel dansk, historie og samfundsfag, hvor man aktivt arbejder med at sætte vores hverdagsforståelse i perspektiv, ligesom kreative fag som billedkunst og håndværk \& design har væsentlige bidrag. En udvikling af den digitale myndiggørelse kunne med fordel blive farvet af faglærernes perspektiver. De fremhævede eksempler viser, at det allerede nu er muligt at arbejde med perspektiverne beskrevet i artiklen, men de gode eksempler bør også påvirke rammerne for et eventuelt kommende fag. Det er netop de inspirerende eksempler, som var inspiration for denne artikel.

\section{Referencer}

Andersen, I.-E. \& Jæger, B. (1999). Scenario workshops and consensus conferences: Towards more democratic decision-making. Science and Public Policy, 26(5), 331-340. https://doi.org/10.3152/147154399781782301

Andersen, J. G. (2004). Et ganske levende demokrati. Aarhus Universitetsforlag.

Andersen, P. D. \& Rasmussen, B. (2012). Fremsyn: Metoder, praksis og erfaringer. Styrelsen for Forskning og Innovation. Lokaliseret på http://orbit.dtu.dk/ files/7945498/Fremsyn.pdf

Binggeli, A., Frydendahl, J. A., Hansbøl, M., Klausen, M. T. \& Søgaard, P. (2020). Teknologiforståelse som fag: 2. klasse: Vores digitale fremtidsby. Forsøg med teknologiforståelse i folkeskolens obligatoriske undervisning som fag 2 . kl. Lokaliseret på https://xn--tekforsget-6cb.dk/wp-content/uploads/2020/og/2.-Vores-fremtidsby-2.kl_.-som-fag-22.09.20.pdf

Christensen, A. S. (2017). Kompetencer $i$ samfundsfag: En undersøgelse af elevers verbalsproglige og multimodale samfundsfaglige kompetencer $i$ 8. Klasse ifolkeskolen [Ph.d.-afhandling]. Syddansk Universitet, Uddannelsesvidenskab.

Christensen, A. S. \& Møller, S. J. (2020). Kender google din type? Forsøg med teknologiforståelse i folkeskolens obligatoriske undervisning i samfundsfag 9. kl. Lokaliseret på https://xn--tekforsget-6cb.dk/wp-content/uploads/2020/o6/Ken der-google-din-type-9.-kl-Samf.pdf 
Christensen, O. (2021, marts 1). Dannelse er også at forstå teknologi. Folkeskolen.dk. Lokaliseret på https://www.folkeskolen.dk/186683o/dannelse-er-ogsaa-atforstaa-teknologi

Decker, M. \& Ladikas, M. (Red.). (2004). Bridges Between Science, Society and Policy: Technology Assessment - Methods and Impacts. Springer. https://doi. org/10.1007/978-3-662-06171-8

Detjen, J., Kuhn, H.-W., Massing, P., Richter, D., Sander, W. \& Weißeno, G. (2004). Nationale Bildungsstandards für den Fachunterricht in der Politischen Bildung an Schulen. Ein Entwurf GPJE (Gesellsschaft für Politikdidaktik und Politische Jugend und Erwachsenbildung). Wochenschau.

Dindler, C., Smith, R. C. \& Iversen, O. S. (2019). En designtilgang til teknologiforståelse (1. udgave). Dafolo.

Durkheim, É. (2000). Om den sociale arbejdsdeling. Hans Reitzel. (Oprindeligt udgivet i 1893).

Fibiger, J., Lorentzen, R. F., Hjorth, M. \& Pasgaard, N. J. (2019). Digital myndiggørelse fra Kant over Dewey til teknologiforståelse i folkeskolen. Studier i loereruddannelse og -profession, 4(1), 56-76.

Fougt, S. S. \& Philipps, M. R. (2020). Teknologiforståelse - I et scenariedidaktisk perspektiv (1. udgave). Hans Reitzel.

Giddens, A. (1994). Modernitetens konsekvenser (1. udgave). Hans Reitzel. (Oprindeligt udgivet i 1990).

Godtliebsen, A., Nielsen, L., Kiær, K., Lorentzen, R. F. \& Nissen, A. (2020). Kan man vore ven med en robot? Forsøg med teknologiforståelse ifolkeskolens obligatoriske undervisning i dansk 5. kl. Lokaliseret på https://xn--tekforsget-6cb. dk/wp-content/uploads/2020/o6/chatbot-5.kl_.-dansk-26-06-20.pdf

Hagendijk, R. \& Irwin, A. (2006). Public Deliberation and Governance: Engaging with Science and Technology in Contemporary Europe. Minerva, 44(2), 167-184. https://doi.org/10.1007/s11024-006-0012-x

Hansen, T. I. (2020). Teknologiforståelse som praktisk klogskab - Om variation og virksomhedsformer i teknologiforståelse som fag. Unge Poedagoger, 1(1), 64-73.

Hasse, Cathrine, Riis, Søren \& Balslev, Jesper. (2021). En trojansk hest for den digitale sektor? Folkeskolen, 2021(5), 28-30.

Hippel, E. von. (2005). Democratizing innovation: The evolving phenomenon of user innovation. Journal Für Betriebswirtschaft, 55(1), 63-78. https://doi. org/10.1007/s11301-004-0002-8

Iversen, O. S. \& Wagner, M.-L. (2020). Digital myndiggørelse i den danske grundskole. Kvan, 117.

Jungk, R. \& Müllert, N. (1989). Håndbog ifremtidsvcerksteder (2. udgave, 3. oplag). Politisk revy.

Kant, I. (1999). Was ist Aufklärung? Ausgewählte kleine Schriften. Felix Meiner.

Kiær, K. (2020). Min mobiltelefon-Ansigtsløs kommunikation med emojis. Forsøg med teknologiforståelse ifolkeskolens obligatoriske undervisning i dansk $1 . \mathrm{kl}$. Lokaliseret på https://xn--tekforsget-6cb.dk/wp-content/uploads/2020/o6/Minmobiltelefon-1.-kl.-Dansk-26-o6-2020.pdf 
Køhrsen, L., Andersen, B. L., Caprani, O., Christensen, E. P. \& Hejsel, T. (2020) ElevAula. Forsøg med teknologiforståelse ifolkeskolens obligatoriske undervisning som fag 6. $k l$. Lokaliseret på https://xn--tekforsget-6cb.dk/wpcontent/uploads/2020/o6/2.-ElevAula-6.-kl-SOM-FAG.pdf

Marx, K. \& Engels, F. (1976). Det kommunistiske manifest. Tiden. Lokaliseret på https://www.oktobernet.dk/artikler_marxistisk_bibliotek/marx/Det kommunistiske_manifest.pdf (Oprindeligt udgivet i 1848).

Møller, M. Ø. (2019). Professioner. I: C. B. Laustsen \& A. Blok (Red.), Sociologiens problemer (s. 20). Hans Reitzel.

Nielsen, L., Godtliebsen, A., Kiær, K., Lorentzen, R. F. \& Nissen, A. (2020). Overvågning i skolen i år 2030-Utopier og dystopier. Forsøg med teknologiforståelse ifolkeskolens obligatoriske undervisning i dansk 5. kl. Lokaliseret på https://xn--tekforsget-6cb.dk/wp-content/uploads/2020/og/ Overv\%C3\%A5gning-i-skolen-5.kl-dansk-15.09.20.pd

Nowotny, H. (2003). Democratising expertise and socially robust knowledge. Science and Public Policy, 30(3), 151-156. https://doi.org/10.3152/147154303781780461

Popper, R. (2008). Foresight Methodology. I: L. Georghiou, J. C. Harper, M. Keenan, I. Miles \& R. Popper (Red.), The Handbook of Technology Foresight: Concepts and Practice. Edward Elgar Publishing.

Pötzsch, H. (2019). Critical Digital Literacy: Technology in Education Beyond Issues of User Competence and Labour-Market Qualifications. TripleC: Communication, Capitalism \& Critique. Open Access Journal for a Global Sustainable Information Society, 17(2), 221-240. https://doi.org/10.31269/triplec. v17i2.1093

Rasmussen, B., Andersen, P. D. \& Borch, K. (2010). Managing Transdisciplinarity in Strategic Foresight. Creativity and Innovation Management, 19(1), 37-46. https:// doi.org/10.1111/j.1467-8691.2009.00534.x

Raworth, K. (2017). Doughnut economics: Seven ways to think like a 21st-century economist. Random House Business.

Rosa, H. (2014). Fremmedgørelse og acceleration (M. Visby, Overs.; 1. udgave). Hans Reitzel.

Undervisningsministeriet. (2018a). Lœeseplan for forsøgsfaget teknologiforståelse. Lokaliseret på https://emu.dk/sites/default/files/2019-02/GSK.\%2O

L\%C3\%A6seplan.Tilg\%C3\%A6ngelig.\%2oTeknologiforst\%C3\%A5else.\%2opdf.pdf

Undervisningsministeriet. (2018b). Teknologiforståelse - Måloversigt. Lokaliseret på https://emu.dk/sites/default/files/2019-02/GSK.\%20F\%C3\%A6lles\%2 M\%C3\%A5l.\%2oTilg\%C3\%A6ngelig.\%2oTeknologiforst\%C3\%A5else.pdf

Zuboff, S. (2019). Overvågningskapitalismens tidsalder: Kampen for en menneskelig fremtid ved magtens nye frontlinje (J. Levinsen, Overs.; 1. udgave). Information. 